\title{
Optimization of Corynebacterium glutamicum immobilization process on bacterial cellulose carrier and its application for lysine fermentation
}

\author{
Tran Thi Minh Tam ${ }^{1}$, Nguyen Thuy Huong ${ }^{1}$ \\ ${ }^{1}$ Department of Biotechnology, Ho Chi Minh City University of Technology, Vietnam
}

\begin{abstract}
Bacterial cellulose (BC) was used as a modern carrier in immobilization of cell. The immobilization of Corynebacterium glutamicum using bacterial cellulose (BC) as a carrier was carried out in two steps: adsorption and incubation. The screening method Plackett-Burman Design was used to identify the significantly influenced factors and the experiments were designed by Response Surface Methodology having the Central Composite Design (RSM-CCD). The obtained immobilization parameters were the cell density of 6.6 billion clone form units per milliliter, the weight of $\mathrm{BC}$ of $10 \mathrm{~g} / 100 \mathrm{~mL}$, the adsorption time of 6.82 hours with the shaking speed of $150 \mathrm{rpm}$ and immobilized cell was incubated at $30^{\circ} \mathrm{C}$ for 3 days. The optimal efficiency of this immobilization reached $72.4 \%$ and the average density of cell on $\mathrm{BC}$ carrier was achieved $47.7 \pm 0.02$ billion clone form units per gram of finished product. These were fermented to receive L-lysine, the number reusing times of immobilized cell was eight, and the lysine field was $95 \%$ in the eighth time of reusing immobilized cell for fermentation with $26.032 \pm 0.023 \mathrm{~g} / \mathrm{L}$ and volumetric productivity was achieved $0.618 \pm 0.100 \mathrm{~g} /(\mathrm{L} . \mathrm{h})$. Furthermore, this immobile product was maintained under the suitable condition in the sterile water, $\mathrm{pH}=7$. After storing at $4^{0} \mathrm{C}$ for 30 days, the percentage of cell survival was $80 \%$.
\end{abstract}

Keywords: - bacterial cellulose, cell immobilization, Corynebacterium glutamicum, L-lysine, Plackett-Burman matrix, Response Surface Methodology (RSM) - Central Composite Design (CCD)

\section{INTRODUCTION}

L-Lysine is an essential amino acid that is added to feed milling, dairy products and pharmaceutical products in order to make amino acid content in human body and animal equally [1]. The recent research showed that L-Lysine was obtained by fermentation technology using Corynebacterium glutamicum but the efficiency was not high. Lysine fermentation process using immobilized cell of Corynebacterium glutamicum is a novel method all over the world. The most notable advantage of this method is shortening the time for lysine production. Therefore, it is highly effective in economic [2]. Corynebacterium glutamicum VTCC - B - 0632 has overproducing pathway, so it is chosen in research on lysine production. In this study, this bacterium was used as an object in all experiments.

Bacterial cellulose (BC) was used as a carrier with prominent advantages such as durable structure and properties as well, easily utilization in different shapes of fermentation equipment, low-cost and multiple times for reusing. "Adsorption - incubation" method was used in the immobilization of cell using BC as a carrier. In the adsorption step, $\mathrm{BC}$ was soaked in the cell suspension, it becomes inflatable and the bacteria were adsorbed onto the $\mathrm{BC}$ surface due to its porous structure and properties [3]. In the incubation step, the immobilized cell grew owing to the nutritional compounds diffused into BC's space. In this step, not only the density of bacterial cell increased significantly, but also the immobilized cell density was maintained long time.

L-lysine fermentation by an immobilized cell pointed out both some advantages and disadvantages. Lysine field increased because of the reuse of immobilized cell and its shorter fermentation time comparing with free-cell. However, bioreactors of immobilized cell were suitably designed with paddles, system of blowing, feeding inoculums system caused declined efficiency of reusing immobile cells. After reusing the finished products in fermentation, the rate of immobilized cell decreased because some carriers were broken due to paddle and chemical components in fermentation medium. Beside, metabolic ability of immobilized cell in medium was different from that of free cell [4].

Corynebacterium glutamicum contains microcapsule structure reducing harmful effect to cell wall when it survived in bad conditions. Its microcapsule also stores nutrient even if bacteria uses its capsule as nutrient source in essential conditions [1]. However, survived cell percentage after long storage time depends on storage solution components. Sugar concentration and salt concentration inside cells usually are higher than those outside, so cells adsorb much water from outside to inside through cell wall. Absorbed pressure of Corynebacterium glutamicum was among $15-20$ atmosphere [1]. To maintain high number of 
Corynebacterium glutamicum cells on BC carrier for a long time in suitable storage condition, we investigated their stabilization over limited time.

\section{THE MATERIALS AND METHODS}

2.1. Materials, medium and culture conditions

Materials: Corynebacterium glutamicum VTCC - B - 0632 was provided by the Vietnam Type Culture Collection. The bacterial cellulose (BC) was the product obtained by fermenting Acetobacter xylinum $\left(1 \times 1 \times 1 \mathrm{~cm}^{3}\right)$ with the moisture $6 \%$.

Cultural medium: innovated Minimal Medium (MM) with glucose $(20 \mathrm{~g} / \mathrm{L})$, peptone $(10 \mathrm{~g} / \mathrm{L})$, yeast extract $(5 \mathrm{~g} / \mathrm{L}), \mathrm{NaCl}(5 \mathrm{~g} / \mathrm{L})$, agar $(15 \mathrm{~g} / \mathrm{L})$.

Fermentation medium: Broth Medium Corynebacterium glutamicum (BMCG).

Cultural and fermentation conditions: the temperature of $30^{\circ} \mathrm{C}$, the agitation rate of $150 \mathrm{rpm}$.

2.2. The immobilization method onto BC carrier

Corynebacterium glutamicum was immobilized onto BC by two steps: adsorption of cell to BC and incubation. The factors influencing to cell immobilization efficiency in each step was defined in experiments, first step: the added cell density, dimension of carrier, weight of carrier, agitation rate and adsorption time, second step: incubation temperature and time [3].

2.3. The screening experiment to identify significantly effective factors on the cell immobilization efficiency onto BC

Plackett-Burman design was used with 5 factors including added cell density, weight of $\mathrm{BC}$, agitation rate, adsorption time and incubation time. The variable in Plackett-Burman matrix and its effects to cell immobilization efficiency $(\alpha=0.05)$ were indicated in Table 1 . The aim of this experiment is screening the main factors that affect to the efficiency of Corynebacterium glutamicum immobilization using BC as a carrier.

Minitab software (version 17) was used to design 12 screening experiments with 5 factors at two levels of each factor. The experimental data were analyzed and the effect of factors was determined. With the value of $\mathrm{p}<0.05$, the next experiments were conducted with corner values of the main effective factors and the medium level of the rest factors.

2.4. The optimization of parameters of Corynebacterium glutamicum cell immobilization using BC as a carrier With the selected factors of screening experiment, the beginning experiments were carried out with medium and corner level of values to determine the association between immobilization efficiency and effective factors. Based on that, the experiments for response surface methodology having the central composite designs (RMS-CCD) was taken place to determine the function of this relation.

2.5. Lysine fermentation in the immobilized cell on $\mathrm{BC}$ carrier

Bioreactors 1000 milliliters of BMCG medium and 10\% (w/v) immobilized cell on BC. Response: lysine field and the rate of escape cell after the cycle of Lysine fermentation.

2.6. The investigation of immobilized cell density stability

Immobilized cells were stored in aseptic water, $\mathrm{pH}=7.0,4^{\circ} \mathrm{C}$ and then checked the number of survival cell in $\mathrm{BC}$ matrix during storage time.

\subsection{Analyzing method}

2.7.1. Analyzing immobilized finished product

Solution A: obtained from washing finished product three times with sodium salt $0.9 \%$.

Solution B: the finished products were broken mechanically, then, they were decomposed by cellulose enzyme. We diluted the solution A and B to determine immobilized cell yield outside and inside finished product by counting the colonies and the average density of immobilized cell.

2.7.2. Analyzing L-lysine in fermentation broth

The concentration of L-lysine was assayed by acidic ninhydrin method of Chinard (1952).

2.7.3. Analyzing residual sugar in fermentation broth

Residual sugar was measured as glucose in the supernatant fluid by colorimetric DNS method of Miller (1959).

2.7.4. Formula

The average cell density $\left(\frac{\text { cells }}{\mathrm{g}}\right)=\frac{\text { immobilized cells inside }+ \text { immobilized cell outside }}{\text { the weight of the finished product }}$

The immobilization efficiency $(\mathrm{H}, \%)=\frac{\text { total of immobilized cells onto } \mathrm{BC}}{\text { total inoculum cells }} * 100 \%$

\section{RESULT}

Corynebacterium glutamicum was grown in the cultural medium with the volume of 100 milliliters, temperature of $30^{\circ} \mathrm{C}$, agitation rate of $150 \mathrm{rpm}$. After 24 fermenting hours, the maximum cell density was 200 billion cells per liter. 
3.1. Screening main effective factors of the cell immobilization efficiency

The average cell immobilization efficiency and the effective values obtained from Plackett-Burman matrix by experiments were illustrated in Table 1. Two factors influenced notably in cell immobilization efficiency $(\mathrm{p}<$ $0.05)$ were cell density and adsorption time. The added cell density factor had the greatest effect value $(-19.21, \mathrm{p}$ $=0.002)$ of all factors in the experiments, followed by adsorption time factor $(-10.35, p=0.028)$. The remaining factors had not effect significantly in designed experiments $(p>0.05)$.

Table 1. The factors in Plackett-Burman matrix and its effect to immobilization efficiency

\begin{tabular}{|l|c|c|c|c|c|}
\hline \multirow{2}{*}{ Name of factors } & \multirow{2}{*}{$\begin{array}{c}\text { Symbols } \\
\text { of factors }\end{array}$} & $\begin{array}{c}\text { Vow } \\
\text { Nalues of factors }\end{array}$ & $\begin{array}{c}\text { High } \\
(+1)\end{array}$ & Main effect & p-value \\
& & $(-1)=86.5 \%)$ & \\
\hline The weight of carrier (g/100mL) & $\mathrm{X}_{1}$ & 5 & 15 & -1.97 & 0.604 \\
\hline $\begin{array}{l}\text { The density of added cell }\left(10^{6} \text { cells }\right. \\
\text { per milliliter) }\end{array}$ & $\mathrm{X}_{2}$ & 3000 & 6000 & -19.21 & 0.002 \\
\hline Adsorption time (hours) & $\mathrm{X}_{3}$ & 2 & 6 & -10.35 & 0.028 \\
\hline The agitation rate (rpm) & $\mathrm{X}_{4}$ & 100 & 300 & -1.11 & 0.768 \\
\hline Incubation time (days) & $\mathrm{X}_{5}$ & 2 & 4 & -3.88 & 0.322 \\
\hline
\end{tabular}

3.2. The optimal values of parameters in immobilized process on $\mathrm{BC}$ carrier to maximum the immobilization efficiency

We determined the relationship between cell immobilization efficiency and two main effective factors through 9 initial experiments.

The analyzing data demonstrated R-sq $=96.9 \%$ and Lack of fit test having p-value of 0.03 . This meant that the immobilization efficiency and two main effective factors were not in the linear relationship. We identified the function of the poly-nominal regression accurately, the experiments for response surface methodology having the central composite designs (RSM-CCD) with the main effective factors $(-\alpha,-1,0,+1$, $+\alpha)$ were conducted. The cell immobilization efficiency and the average immobilized cell on BC were got responses. The highest cell immobilization efficiency was run-1 $\left(x_{2}=-\alpha, x_{3}=0\right)$ of all experiments, which was reached $69.5 \pm 0.025 \%$. However, run-2 $\left(\mathrm{x}_{2}=+\alpha, \mathrm{x}_{3}=0\right)$ had the biggest average immobilized cell on $\mathrm{BC}$ (30.1 \pm 0.11 billion clone form units per gram) of all experiments.

In this case, we determined the relationship between the main effective factors and response (the cell immobilization efficiency). The poly-nominal regression equation was determined below:

Response, $y=248.2-0.005 * x_{2}-8.21 * x_{3}-0.981 * x_{3}^{2}+0.00005 * x_{2} * x_{3}$

In the above equation, y (\%) symbols for cell immobilization efficiency, $\mathrm{x}_{2}\left(10^{6}\right.$ cells $\left./ \mathrm{mL}\right)$ symbols for added cell density and $\mathrm{x}_{3}$ (days) symbols for adsorption time.

The regression equation (3.1) showed that two factors (added cell density factor and adsorption time factor) were positively affected on the formation of the cell immobilization efficiency. In fact, the adsorption time factor had the strongest influence level in all factors. This factor was decreased, the response would be increased. The added cell density factor was also decreased to improve the cell immobilization efficiency. And, the response was been high, the 2-way interaction $\left(\mathrm{X}_{2} * \mathrm{X}_{3}\right)$ was increased. However, they are non-linear, they change in certain limitation.

Table 2. Corynebacterium glutamicum cell immobilization efficiency and average immobilized cell on BC carrier by RSM-CCD experiments.

\begin{tabular}{|c|c|c|c|c|c|c|}
\hline \multirow[t]{2}{*}{ Runs } & \multicolumn{2}{|c|}{ Code units } & \multicolumn{2}{|c|}{ Uncoded values } & \multirow{2}{*}{$\begin{array}{c}\text { The average } \\
\text { immobilized cell } \\
\left(10^{9} \text { cells } / \mathrm{g}\right)\end{array}$} & \multirow{2}{*}{$\begin{array}{c}\text { Response, } \mathrm{Y} \\
(\%)\end{array}$} \\
\hline & $\mathrm{X}_{2}$ & $\mathrm{X}_{3}$ & $\begin{array}{c}\mathrm{X}_{2} \\
\left(10^{6} \mathrm{cells} / \mathrm{mL}\right)\end{array}$ & $\begin{array}{c}\mathrm{X}_{3} \\
\text { (hours) }\end{array}$ & & \\
\hline 1 & -1.4 & 0.0 & 2385 & 4.0 & $16.6 \pm 0.06$ & $69.5 \pm 0.025$ \\
\hline 2 & 1.4 & 0.0 & 6615 & 4.0 & $30.1 \pm 0.11$ & $45.5 \pm 0.017$ \\
\hline 3 & -1.0 & 1.0 & 3000 & 6.0 & $10.0 \pm 0.04$ & $33.3 \pm 0.013$ \\
\hline 4 & 0.0 & 0.0 & 4500 & 4.0 & $1.0 \pm 0.01$ & $2.1 \pm 0.002$ \\
\hline 5 & 0.0 & -1.4 & 4500 & 1.2 & $4.0 \pm 0.02$ & $9.0 \pm 0.004$ \\
\hline 6 & 0.0 & 0.0 & 4500 & 4.0 & $1.7 \pm 0.01$ & $3.8 \pm 0.002$ \\
\hline 7 & 1.0 & 1.0 & 6000 & 6.0 & $17.4 \pm 0.06$ & $29.0 \pm 0.010$ \\
\hline 8 & 0.0 & 0.0 & 4500 & 4.0 & $1.0 \pm 0.01$ & $2.1 \pm 0.002$ \\
\hline 9 & 0.0 & 1.4 & 4500 & 6.8 & $13.2 \pm 0.05$ & $29.4 \pm 0.010$ \\
\hline 10 & 0.0 & 0.0 & 4500 & 4.0 & $1.7 \pm 0.01$ & $3.8 \pm 0.002$ \\
\hline 11 & 1.0 & -1.0 & 6000 & 2.0 & $2.6 \pm 0.02$ & $4.3 \pm 0.003$ \\
\hline 12 & -1.0 & -1.0 & 3000 & 2.0 & $6.2 \pm 0.03$ & $20.7 \pm 0.010$ \\
\hline 13 & 0.0 & 0.0 & 4500 & 4.0 & $1.7 \pm 0.01$ & $3.8 \pm 0.002$ \\
\hline
\end{tabular}


The analysis of variance indicated that the above poly-nominal regression function got R-sq $=88.94 \%$. We used response optimizer tool in Minitab 17 to indentify the combination of predictor values that jointly optimize one. The highest value of response (y) was $72.4 \%$ with established optimal parameters as below: added cell density of 6.6 (billion clone form units per milliliter), the weight of carrier of $10 \mathrm{~g} / 100 \mathrm{~mL}$, adsorption for 6.82 hours with the shaking speed of $150 \mathrm{rpm}$, incubation for 3 days at $30^{\circ} \mathrm{C}$. We immobilized Corynebacterium glutamicum VTCC-B-0632 on BC carrier with optimal parameters and identified the average cell on BC was achieved $47.7 \pm 0.02$ (billion clone form units per gram).

3.3. Lysine fermentation in the immobilized cell on BC carrier

Finished product was fermented to receive L-lysine on BMCG medium.

Table 3. Lysine field and the escaped cell rate in Lysine fermentation by immobilized cell on BC carrier

\begin{tabular}{|c|c|c|c|c|c|c|c|c|c|c|}
\hline \multirow[t]{2}{*}{ Response, Y } & \multicolumn{10}{|c|}{ The reusing finished product times } \\
\hline & 1 & 2 & 3 & 4 & 5 & 6 & 7 & 8 & 9 & 10 \\
\hline $\begin{array}{c}\text { Lysine yield } \\
\left(\mathrm{g} . \mathrm{L}^{-1}\right)\end{array}$ & $\begin{array}{c}32.500 \\
\pm\end{array}$ & $\begin{array}{c}31.082 \\
\pm\end{array}$ & $\begin{array}{c}31.067 \\
\pm\end{array}$ & $\begin{array}{c}31.003 \\
\pm\end{array}$ & $\begin{array}{c}29.999 \\
\pm\end{array}$ & $\begin{array}{c}28.025 \\
\pm\end{array}$ & $\begin{array}{c}27.700 \\
\pm\end{array}$ & $\begin{array}{c}26.032 \\
\pm\end{array}$ & $\begin{array}{c}22.212 \\
\pm\end{array}$ & $\begin{array}{c}15.215 \\
\pm\end{array}$ \\
\hline Mean \pm SD & $0.200^{\mathrm{a}}$ & $0.100^{\mathrm{a}}$ & $0.551^{\mathrm{a}}$ & $0.223^{\mathrm{a}}$ & $0 . \overline{6} 11^{\mathrm{b}}$ & $0 . \overline{2} 21^{\mathrm{b}}$ & $0 . \overline{55} 7^{\mathrm{b}}$ & $0.023^{\mathrm{c}}$ & $0 . \overline{252^{\mathrm{d}}}$ & $0 . \overline{5} 21^{\mathrm{e}}$ \\
\hline $\begin{array}{l}\text { The escaped } \\
\text { cell rate }(\%) \\
\text { Mean }+ \text { SD }\end{array}$ & $\begin{array}{c}4.667 \\
\pm \\
0.528^{\mathrm{a}}\end{array}$ & $\begin{array}{c}5.067 \\
\pm \\
0.052^{\mathrm{a}}\end{array}$ & $\begin{array}{l}6.060 \pm \\
0.002^{\mathrm{a}}\end{array}$ & $\begin{array}{c}6.074 \\
\pm \\
0.050^{\mathrm{a}}\end{array}$ & $\begin{array}{c}9.076 \pm \\
0.025^{\mathrm{a}}\end{array}$ & $\begin{array}{c}15.075 \\
\pm \\
2.500^{\mathrm{b}}\end{array}$ & $\begin{array}{c}19.047 \\
\pm \\
1.245^{\mathrm{c}}\end{array}$ & $\begin{array}{c}24.670 \\
\pm \\
2.520^{\mathrm{d}}\end{array}$ & $\begin{array}{l}37.578 \\
\pm 6.23^{\mathrm{e}}\end{array}$ & $\begin{array}{c}56.000 \\
\pm \\
5.290^{\mathrm{f}}\end{array}$ \\
\hline & & & & & & & & $0,05)$ & & roth \\
\hline
\end{tabular}

In Lysine fermentation by the immobilized cell, Lysine yield decreased gradually over fermentation cycling. When finished products were reuse at eighth time, the Lysine yield in broth was not significantly different ( $\mathrm{p}<0.05)$, but it went down by $31.6 \pm 0.3 \%$ and $51.9 \pm 1.3 \%$ in the ninth fermentation and tenth one respectively. Furthermore, escaped cell rate in broth increased over fermentation cycling. In ninth fermentation, it was bottomed at $37.6 \pm 6.2 \%$ and this proportion was $56.0 \pm 5.3 \%$ in the tenth fermentation.

3.4. The comparison Lysine yield in fermentation broth between immobilized cell and free cell We conducted some experiments on free cell and immobilized cell on $\mathrm{BC}$, in order to determinate the differences about Lysine yield (Table 4).

After eighth reusing times, the total of Lysine yield was $237.048 \pm 1.023 \mathrm{~g} . \mathrm{L}^{-1}$. It was higher than in free cell fermentation. But, the average of Lysine yield per batch in immobilized cell fermentation was slightly lower than in free-cell one (29.67 vs 32.6), they were not significant in analyzing statistics ( $<<0.05)$. Especially, Lysine productivity in the immobilized cell bioreactor was higher by $36 \%$ than that in free cell tank (0.618 vs $0.453)$.

Table 4. Compare Lysine yield in fermentation broth between immobilized cell and free cell

\begin{tabular}{|c|c|c|c|c|c|c|}
\hline Objects & $\begin{array}{c}\text { Fermenting } \\
\text { time per } \\
\text { reusing } \\
\text { (hours) }\end{array}$ & $\begin{array}{c}\text { The number } \\
\text { of reusing } \\
\text { times } \\
\text { (times) }\end{array}$ & $\begin{array}{c}\text { Total of } \\
\text { fermenting } \\
\text { time (hours) }\end{array}$ & $\begin{array}{c}\text { Total of Lysine } \\
\text { yield in broth } \\
\left(\mathrm{g} . \mathrm{L}^{-1}\right)\end{array}$ & $\begin{array}{c}\text { The average of } \\
\text { Lysine yield per } \\
\text { batch } \\
\left(\mathrm{g} . \mathrm{L}^{-1}\right)\end{array}$ & $\begin{array}{c}\text { Lysine } \\
\text { productivity } \\
\left(\mathrm{g} . \mathrm{L}^{-1} \cdot \mathrm{h}^{-1}\right)\end{array}$ \\
\hline $\begin{array}{c}\text { The } \\
\begin{array}{c}\text { immobil } \\
\text { ized cell } \\
\text { on BC }\end{array}\end{array}$ & 48 & 8 & 384 & $237.408 \pm 1.023$ & $29.676 \pm 0.900^{\mathrm{a}}$ & $0.618 \pm 0.100^{\mathrm{c}}$ \\
\hline Free cell & 72 & 1 & & $32.600 \pm 0.400$ & $32.600 \pm 0.400^{\mathrm{b}}$ & $0.453 \pm 0.006^{\mathrm{c}}$ \\
\hline
\end{tabular}

3.5. The chances in clone form units of immobilized Corynebacterium glutamicum on BC carrier over storage time

Finished product was stored in sterile water, $\mathrm{pH}=7,4^{\circ} \mathrm{C}$. Clone form units were checked and counted over 60 days. 


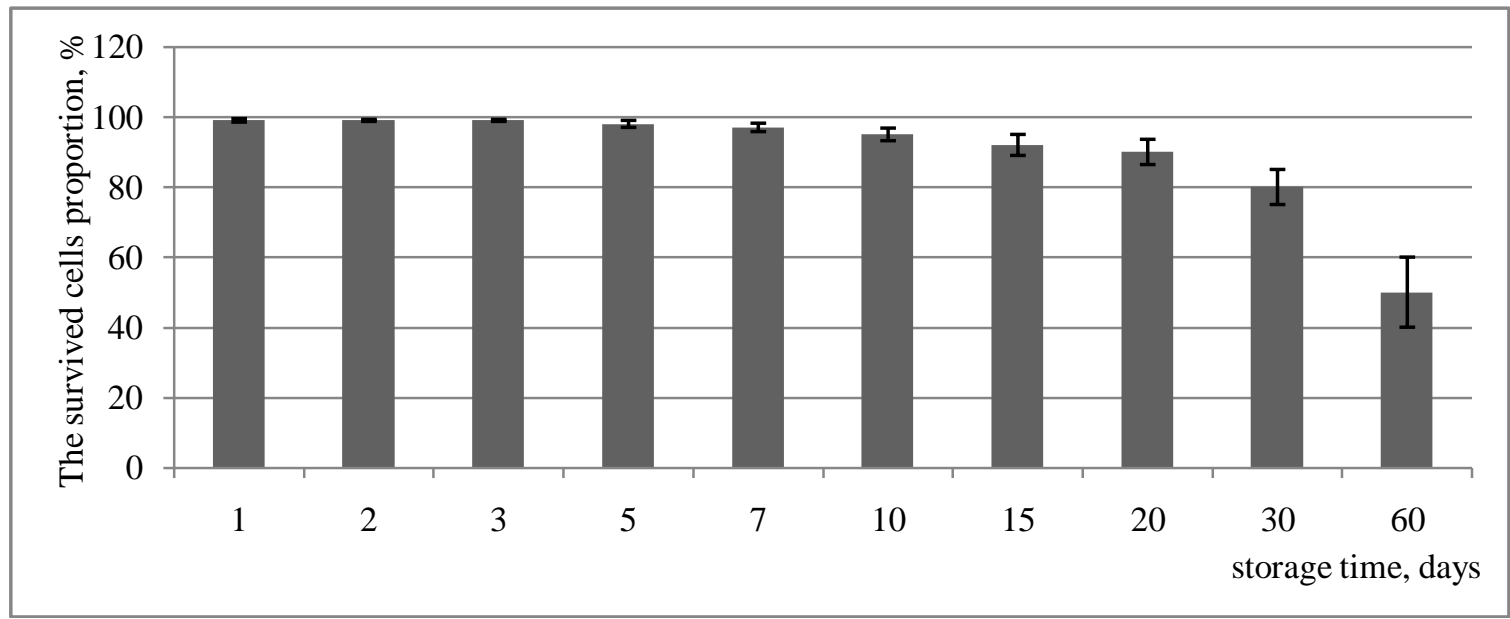

Figure 1. The percentage of survived cell on BC after 60 days

In the first stage from 1 day to 10 days, the percentage of survived cell in BC carrier was at $100 \%$. But, it was decreased when immobile cells were stored in this condition. In particular, the percentage of survived cell on BC after 20 days and 30 days were $90 \%$ and $80 \%$, respectively. The proportion of survived cell on BC was $50 \%$ after 60 storage days.

\section{DISCUSSION}

4.1. The optimal values of parameters in immobilized process on BC carrier

BC carrier has certain surface area and the quantity of utilized BC in this study was contained. Therefore, increasing concentration of Corynebacterium glutamicum suspension caused the number of adsorbed cell onto $\mathrm{BC}$ going up to a specific value without linear relationship. This result was suitable with research of Le Van Viet Man (2009) immobilized yeast onto BC. With the same cell concentration in a suspension, the immobilization efficiency increases as the weight of carrier rises. However, immobilized cell density onto particle carrier decreases while weight of carrier rises [3]. Therefore, in the incubation step, there is enough space in BC for Corynebacterium glutamicum cell growth. Moreover, the shaking speed influences to the arrangement of cell and carrier. With a suitable agitation rate, the cell immobilization obtained higher efficiency.

On the other hand, BC is spongy enough for nutrition compounds to diffuse into space inside BC so that Corynebacterium glutamicum growth is able to occur. Therefore, after incubation, the cell immobilization density increased. However, immobilized products would be destroyed and cell density would be decreased if there were an unsuitable time and temperature in the incubation step [3].

4.2. Lysine fermentation in immobilized Corynebacterium glutamicum on BC carrier

Fermentation process by immobilized cell on $\mathrm{BC}$ was depended on the number of $\mathrm{BC}$ pieces. They contain cell density, it means, the more $\mathrm{BC}$ pieces that put in the tank is the more clone form units in fermentation system. They were led to the mass transfer in tank and Lysine yield was influenced [5].

Using immobilized Corynebacterium glutamicum on BC carrier for Lysine fermentation had many advantages. The Lysine yield was increased due to short fermenting time per batch and immobilized cell reusing. Immobilized cell were used for fermentation had not lag stage as the result of saving time because cells had already been adapted to the environment. Moreover, we had not to prepare inoculums, it means, we did not spend time and money preparing medium.

Compared the free-cell fermentation with immobilized cell fermentation, Lysine productive was significantly improved in both total yield and volumetric productivity as shown in Table 4, it had a similar propionic acid production by immobilized cell [6]. Depending on the production scale, an economically affordable solution, immobilized cell was used for Lysine fermentation.

\section{CONCLUSION}

Corynebacterium glutamicum cell immobilization process onto BC was completed by the design of screening experiments Plackett - Burman and response surface methodology having the Central Composite Design (RSM-CCD). The obtained immobilization parameters were identified and the optimal efficiency of this immobilization reached $72.4 \%$ and the average density of cell on BC carrier was 47.7 billion clone form units per finished product gram. Lysine productivity for immobilized cell was $0.6 \mathrm{~g} . \mathrm{L}^{-1} \cdot \mathrm{h}^{-1}$, it was higher than that for free cell. The proportion of survived cell on BC matrix was achieved $80 \%$ after 30- day- store in sterile water, $\mathrm{pH}$ of 7.0 , at $4^{0} \mathrm{C}$. The disadvantages of the study were not conducted experiments to demonstrate no lag phase in immobilized cell fermentation and the stability of survived cell on BC carrier on different solvents. 
Immobilization of Corynebacterium glutamicum VTCC B 0632 in BC was used in lysine production was hopeful. The number reusing times of immobilized cell in $\mathrm{BC}$ was higher than that in other carriers such as alginate, kappa carrageenan, gellan, .... And $\mathrm{BC}$ will be used for immobilization of different microbial species.

\section{ACKNOWLEDGEMENTS}

We would like to fully appreciate the help of the teachers/professors in the Chemistry Faculty of Ho Chi Minh City University of Technology in this study.

\section{REFERENCES}

[1] Eggeling, L. and M. Bott, Handbook of Corynebacterium glutamicum. 2010: CRC press.

[2] Judith Becker, C.K., Hartwig Schroder, Christoph Wittmann, Metabolic Engineering of the Tricarboxylic Acid Cycle for Improved Lysine Production by Corynebacterium glutamicum. Applied and Environmental Microbiology, 2009. 75(24): p. 7866-7869.

[3] Le Van Viet Man, T.N.M.N., Optimization of Saccharomyces cerevisiae immobilization in bacterial cellulose by "adsorption - incubation" method. International Food Research Journal, 2009. 16(1): p. 5664 .

[4] Velizarov, S.G., Rainina, E. I., Sinitsyn, A. P., Varfolomeev, S. D., and V.I.a.Z. Lozinsky, A. L. , Production of L-lysine by free and PVA-cryogel immobilized Corynebacterium glutamicum cells. Biotechnology advances, 1992. 14: p. 291-296.

[5] Rao, B., C.V. Murthy, and A. Swamy, Studies on Continuous Reactor Kinetics of L-Lysine by Immobilized Corynebacterium glutamicum Cells. IUP Journal of Chemical Engineering, 2011. 3(2): p. 7 $-16$.

[6] Huang, Y.L., et al., Production of carboxylic acids from hydrolyzed corn meal by immobilized cell fermentation in a fibrous-bed bioreactor. Bioresource technology, 2002. 82(1): p. 51-59. 